\title{
EFFECT OF NEUTRALISING SUBSTANCES ON SELECTED PROPERTIES OF SOIL CONTAMINATED WITH COBALT
}

\author{
Milena Kosiorek ${ }^{1}$, Mirosław Wyszkowski ${ }^{1}$ \\ 1 Department of Environmental Chemistry, University of Warmia and Mazury in Olsztyn, 4 Łódzki Sq., 10-727 \\ Olsztyn, Poland, e-mail: miroslaw.wyszkowski@uwm.edu.pl
}

Received: 2016.04.13 Accepted: 2016.06.01 Published: 2016.07.01

\begin{abstract}
Because of the potential threat for development of plants, resulting from the occurrence of too high cobalt contents in soil environment, a study was undertaken aiming to determine the effect of increasing soil contamination with cobalt $(0,20,40,80,160,320$ $\mathrm{mg} \cdot \mathrm{kg}^{-1}$ of soil), following the application of neutralising substances (farmyard manure, loam, charcoal, zeolite and calcium oxide), on the soil $\mathrm{pH}$, hydrolytic acidity, total exchangeable bases, cation exchange capacity and the base saturation. In the series without neutralising substances added, soil contamination with the highest doses of cobalt resulted in a decrease in $\mathrm{pH}$, in the total exchangeable bases, in the cation exchange capacity, and in the base saturation, and in an increase in the soil hydrolytic acidity. Of the applied neutralising substances, farmyard manure and particular calcium oxide had the greatest effect on the analysed soil properties. The application of the substances resulted in an increase in the soil $\mathrm{pH}$, in the base exchange capacity, in the cation exchange capacity and in the base saturation and also in a decrease in the soil hydrolytic acidity. The other substances had no, or a small, effect on the studied soil properties.
\end{abstract}

Keywords: cobalt contamination, farmyard manure, loam, charcoal, zeolite, calcium oxide, soil properties.

\section{INTRODUCTION}

The content of heavy metals in soil depends on both natural and anthropogenic factors. Among the natural factors there are weathering of rocks, volcanic processes, evaporation of the oceans and forest fires. The anthropogenic factors mainly include the activity of various branches of industry, combined heat and power engineering industry, road transportation and intensive agricultural production [Bezerra et al. 2014, Li et al. 2014, Micó et al. 2008, Zupancic, Skobe 2014]. Because of the rapid development of the civilisation in recent years, the anthropogenic factors have become the main source of soil contamination with heavy metals [Kierczak et al. 2008] having a strong effect on the soil properties [Wyszkowski, Wyszkowska 2009].
One of the heavy metals which accumulate in soil is cobalt. A natural source of its occurrence in soil are such minerals as cobaltite, smaltite, linnaeite and safflorite. Large contents of cobalt in soil also accumulate in igneous and sedimentary rocks [Luo et al. 2010]. An increase in the cobalt content in soil environment results mainly from human activity connected with cobalt mining works, with the application of fertilisers, pesticides, chemical agents, with wastewater treatment, combustion of fuels, production of steel, catalysts, lacquers or paints [Bezzera et al. 2014, Biswas et al. 2013, Saaltink et al. 2014, Mico et al. 2008, Werkenthin et al. 2014, Zupancic, Skobe 2014].

Cobalt plays an important role in the proper development of plants. Its indispensability is particularly apparent in the case of leguminous plants because, thanks to their symbiosis with rhizobia, fixation of molecular nitrogen is possi- 
ble [Collins, Kinsela 2011, Wyszkowski, Wyszkowska 2007]. Both too low and too high cobalt content in plants may result in harmful health effects [Chatterjee, Chatterje 2002]. In case of exceeding the acceptable cobalt content in a plant, cobalt also accumulates in further links of the food chain. Because of this, cobalt not only poses a threat for plants, but also for animals and for humans [Devi et al. 2014]. Most often cobalt is taken up by plants in the form of $\mathrm{Co}^{2+}$ ions, or in a form of chelates [Karuppanapandian, Kim 2013]. The size and intensity of cobalt uptake from soil by plants depends to a great degree on soil properties [Edwards et al. 2012, Wendling et al. 2009].

Because of the potential threat for development of plants, resulting from the occurrence of too high cobalt contents in soil environment, a study was undertaken aiming to determine the effect of increasing soil contamination with cobalt, following an application of neutralising substances, on the soil $\mathrm{pH}$, hydrolytic acidity, total exchangeable bases, cation exchange capacity and the base saturation.

\section{MATERIAL AND METHODS}

An experiment was conducted in the vegetation hall of the University of Warmia and Mazury in Olsztyn, in polyethylene pots holding $9 \mathrm{~kg}$ of soil. Before the experiment, the soil had the following properties: $\mathrm{pH}$ in a $1 \mathrm{M} \mathrm{KCl}$ solution 5.05 ; hydrolytic acidity $-28.40 \mathrm{mmol}(+) \cdot \mathrm{kg}^{-1}$; total exchangeable bases $-46.50 \mathrm{mmol}(+) \cdot \mathrm{kg}^{-1}$; cation exchange capacity $-74.90 \mathrm{mmol}(+) \cdot \mathrm{kg}^{-1}$; the base saturation $-68.08 \%$. The soil was contaminated with increasing doses of cobalt: 0,20 , $40,80,160,320 \mathrm{mg} \cdot \mathrm{kg}^{-1}$ of soil, in a form of cobalt chloride. In the experiment, neutralising substances were applied, in the form of farmyard manure, loam, charcoal, zeolite in an amount of $2 \%$ based on the weight of the soil, and calcium oxide in a dose corresponding to $1 \mathrm{Hh}$. In order to secure the plants' nutritional requirements, all pots additionally received mineral components in the following amounts: $100 \mathrm{mg} \mathrm{N} ; 35 \mathrm{mg} \mathrm{P}$; $100 \mathrm{mg} \mathrm{K} ; 50 \mathrm{mg} \mathrm{Mg}$; $0.33 \mathrm{mg} \mathrm{B} ; 5 \mathrm{mg} \mathrm{Mn}$ and $5 \mathrm{mg} \mathrm{Mo} \cdot \mathrm{kg}^{-1}$ of soil. The main plant in the experiment was spring barley (Hordeum vulgare L.) of the cultivar Mercada, and the successive plant was white mustard (Synapis alba L.) of the cultivar Bamberka. The spring barley harvest was performed in the ear-forming phase and the white mustard harvest in the flowering phase. The re- search material was soil sampled after the harvest of the successive plant.

The soil, before performing the laboratory analyses, was dried in the open air, and then sieved through a $1 \times 1 \mathrm{~mm}$ mesh. The soil $\mathrm{pH}$ in a $1 \mathrm{M} \mathrm{KCl}$ solution was determined potentiometrically, and the hydrolytic acidity (HAC), and the total exchangeable bases (TEB) were determined with the Kappen method [Ostrowska et al. 1991]. The cation exchange capacity (CEC) was computed based on the formula $\mathrm{CEC}=\mathrm{TEB}$ $+\mathrm{HAC}$, and the base saturation (BS) according to the formula $\mathrm{BS}=(\mathrm{TEB}: \mathrm{CEC}) \cdot 100$ [Ostrowska et al. 1991]. The statistical analysis of the obtained study results was performed with Statistica 12.0 software.

\section{RESULTS AND DISCUSSION}

Based on the obtained results, it was found that both soil contamination with cobalt, and the applied neutralising substances had a significant effect on the analysed soil properties (Tables 1-2). In the series without neutralising substances added, introducing increasing doses of cobalt into the soil resulted in a decrease in the soil $\mathrm{pH}$ from 6.03 to $5.32(\mathrm{r}=-0.552)$. The greatest decrease in $\mathrm{pH}$ was noted in the objects with 80 and 160 $\mathrm{mg} \mathrm{Co} \cdot \mathrm{kg}^{-1}$ of soil added. With decreasing soil $\mathrm{pH}$, the hydrolytic acidity increased $(\mathrm{r}=-0.506)$. Soil contamination with cobalt also had an effect on a decrease in the total exchangeable bases, from 75.81 to $49.61 \mathrm{mmol}(+) \cdot \mathrm{kg}^{-1}$ of soil $(\mathrm{r}=$ -0.985), in the cation exchange capacity from 105.89 to $85.21 \mathrm{mmol}(+) \cdot \mathrm{kg}^{-1}$ of soil $(\mathrm{r}=-0.789)$ and in the degree of saturation of the soil with base cations from 71.59 to $58.32 \mathrm{mmol}(+) \cdot \mathrm{kg}^{-1}$ of soil $(\mathrm{r}=-0.759)$. According to Collins and Kinsel [2011] and Lange et al. [2014], low soil pH promotes excessive uptake of cobalt from soil by a plant, which may result in the appearance of diseases or dying out of plants.

Of the applied neutralising substances, the greatest and significant effect on the analysed soil properties had calcium oxide. Following its introduction into soil, there was a significant increase in the $\mathrm{pH}$ to the value of $\mathrm{pH}>7$ and a decrease in the hydrolytic acidity by $40 \%$ on average, compared to the series without additions. Increasing soil $\mathrm{pH}$ also resulted in an increase in the total exchangeable bases by up to $73 \%$ on average, in the cation exchange capacity by $31 \%$ and in the base saturation by $32 \%$, compared to the series 
Table 1. Effect of cobalt contamination on $\mathrm{pH}$, hydrolitic acidity and total exchange bases in soil

\begin{tabular}{|c|c|c|c|c|c|c|c|}
\hline \multirow{2}{*}{$\begin{array}{l}\text { Dose of cobalt } \\
{\left[\mathrm{mg} \cdot \mathrm{kg}^{-1} \text { of soil }\right]}\end{array}$} & \multicolumn{7}{|c|}{ Kind of substance neutralizing effect of cobalt } \\
\hline & $\begin{array}{c}\text { without } \\
\text { additions }\end{array}$ & manure & loam & charcoal & zeolite & calcium oxide & average \\
\hline \multicolumn{8}{|c|}{$\mathrm{pH}_{\mathrm{KCl}}$} \\
\hline 0 & 6.03 & 6.49 & 6.05 & 6.13 & 5.94 & 7.45 & \\
\hline 20 & 5,89 & 6.43 & 6.05 & 6.06 & 5.97 & 7.37 & \\
\hline 40 & 5.46 & 6.25 & 5.48 & 6.04 & 5.76 & 7.45 & \\
\hline 80 & 5.04 & 6.16 & 5.60 & 5.50 & 5.43 & 7.48 & \\
\hline 160 & 5.07 & 5.69 & 5.23 & 5.29 & 5.43 & 7.40 & \\
\hline 320 & 5.32 & 6.10 & 5.25 & 5.91 & 5.75 & 7.31 & \\
\hline$r$ & -0.552 & $-0.592^{*}$ & $-0.782^{* *}$ & -0.333 & -0.345 & $-0.719^{* *}$ & \\
\hline LSD & \multicolumn{7}{|c|}{$a-0.05^{* *}, b-0.05^{* *}, a \cdot b-0.12^{* *}$} \\
\hline \multicolumn{8}{|c|}{ Hydrolitic acidity (HAC) $\left[\mathrm{mmol}(+) \cdot \mathrm{kg}^{-1}\right.$ of soil] } \\
\hline 0 & 30.08 & 24.41 & 31.19 & 26.78 & 32.29 & 19.69 & 27.41 \\
\hline 20 & 32.45 & 27.09 & 31.50 & 28.51 & 28.19 & 21.89 & 28.27 \\
\hline 40 & 34.34 & 29.61 & 32.76 & 26.46 & 31.66 & 17.80 & 28.77 \\
\hline 80 & 38.43 & 31.19 & 34.81 & 33.08 & 35.75 & 20.00 & 32.21 \\
\hline 160 & 38.27 & 35.60 & 36.23 & 34.02 & 34.49 & 23.63 & 33.71 \\
\hline 320 & 35.60 & 30.71 & 34.81 & 31.50 & 34.34 & 21.58 & 31.42 \\
\hline Average & 34.86 & 29.77 & 33.55 & 30.06 & 32.79 & 20.77 & 30.30 \\
\hline$r$ & 0.506 & $0.561^{*}$ & $0.702^{* *}$ & $0.594^{*}$ & 0.533 & 0.460 & $0.635^{*}$ \\
\hline LSD & \multicolumn{7}{|c|}{$a-0.74^{* *}, b-0.74^{* *}, a \cdot b-1.81^{* *}$} \\
\hline \multicolumn{8}{|c|}{ Total exchangeable bases $($ TEB $)\left[\mathrm{mmol}(+) \cdot \mathrm{kg}^{-1}\right.$ of soil $]$} \\
\hline 0 & 75.81 & 76.81 & 77.86 & 71.61 & 63.79 & 102.48 & 78.06 \\
\hline 20 & 61.11 & 71.29 & 71.61 & 65.42 & 60.80 & 96.86 & 71.18 \\
\hline 40 & 59.22 & 63.32 & 65.84 & 75.13 & 65.26 & 109.78 & 73.09 \\
\hline 80 & 58.54 & 63.11 & 62.32 & 60.59 & 53.13 & 115.34 & 68.84 \\
\hline 160 & 53.34 & 56.07 & 54.13 & 54.18 & 52.08 & 99.75 & 61.59 \\
\hline 320 & 49.61 & 68.15 & 48.46 & 52.55 & 49.25 & 95.71 & 60.62 \\
\hline Average & 59.61 & 66.46 & 63.37 & 63.25 & 57.39 & 103.32 & 68.90 \\
\hline$r$ & $-0.789^{* *}$ & -0.325 & $-0.927^{* *}$ & $-0.829^{* *}$ & $-0.841^{* *}$ & -0.412 & $-0.887^{* *}$ \\
\hline LSD & \multicolumn{7}{|c|}{$a-1.71^{* *}, b-1.71^{* *}, a \cdot b-4.19^{* *}$} \\
\hline
\end{tabular}

LSD (least squares deviation) for: $\mathrm{a}$ - cobalt dose, $\mathrm{b}$ - kind of neutralizing substance, $\mathrm{a} \cdot \mathrm{b}$ - interaction; significant for: ${ }^{* *}-\mathrm{P}=0.01^{*}-\mathrm{P}=0.05 ; \mathrm{r}-$ correlation coefficient.

without the substances applied. Farmyard manure also had a favourable effect on the $\mathrm{pH}$, hydrolytic acidity and the cation exchange capacity in soil, although its effect was much weaker than the effect of calcium oxide. Of the other neutralising substances, only charcoal caused a decrease in the soil hydrolytic acidity (by $14 \%$ on average). Zeolite and loam did not have a greater effect on the studied soil properties.

The computed correlation coefficients indicate significant relations between all the analysed soil properties (Table 3).

Studies by Kukier et al. [2004] indicate that increasing the soil $\mathrm{pH}$ from 5.8 to 6.8-6.9 may significantly decrease the availability of cobalt to plants. The lesser harmfulness of cobalt occurring in alkaline or neutral soil environment is also confirmed in the study by Wendling et al. [2009]. A favourable effect of calcium oxide on the soil properties analysed in the work was also found by Kosiorek and Wyszkowski [2016], and Wyszkowski and Sivitskaya [2015]. The study by Azeez and Van-Averbeke [2012] confirmed the positive effect of farmyard manure on physico-chemical soil properties, particularly on the soil $\mathrm{pH}$. In the studies by Wyszkowski and Modrzewska [2016], as opposed to experiments by Wyszkowski and Sivitskaya [2015], the effect of compost and zeolite on the abovementioned soil properties was also relatively small. The effect of the zeolite introduced into to soil on an increase in the soil $\mathrm{pH}$ was found by Filcheva and Tsadias [2002] and Singh et al. [2000]. Glisic et al. [2009] also indicated that introducing zeolite into soil with an addition of farmyard manure has a significant effect on a decrease in hydrolytic acidity. 
Table 2. Effect of cobalt contamination on cation exchange capacity and base saturation in soil

\begin{tabular}{|c|c|c|c|c|c|c|c|}
\hline \multirow{2}{*}{$\begin{array}{l}\text { Dose of cobalt } \\
{\left[\mathrm{mg} \cdot \mathrm{kg}^{-1} \text { of soil] }\right.}\end{array}$} & \multicolumn{7}{|c|}{ Kind of substance neutralizing effect of cobalt } \\
\hline & $\begin{array}{l}\text { without } \\
\text { additions }\end{array}$ & manure & loam & charcoal & zeolite & calcium oxide & average \\
\hline \multicolumn{8}{|c|}{ Cation exchange capacity (CEC) $\left[\mathrm{mmol}(+) \cdot \mathrm{kg}^{-1}\right.$ of soil $]$} \\
\hline 0 & 105.89 & 101.22 & 109.04 & 98.39 & 96.08 & 122.17 & 105.46 \\
\hline 20 & 93.55 & 98.38 & 103.11 & 93.92 & 88.99 & 118.76 & 99.45 \\
\hline 40 & 93.56 & 92.93 & 98.60 & 101.59 & 96.92 & 127.58 & 101.86 \\
\hline 80 & 96.97 & 94.29 & 97.13 & 93.66 & 88.88 & 135.35 & 101.05 \\
\hline 160 & 91.61 & 91.67 & 90.35 & 88.20 & 86.57 & 123.38 & 95.30 \\
\hline 320 & 85.21 & 98.86 & 83.27 & 84.05 & 83.58 & 117.29 & 92.04 \\
\hline Average & 94.47 & 96.23 & 96.92 & 93.30 & 90.17 & 124.09 & 99.19 \\
\hline r & $-0.798^{* *}$ & -0.057 & $-0.948^{* *}$ & $-0.880^{* *}$ & $-0.799^{* *}$ & -0.341 & $-0.914^{* *}$ \\
\hline LSD & \multicolumn{7}{|c|}{$a-1.97^{* *}, b-1.97^{* *}, a \cdot b-4.82^{* *}$} \\
\hline \multicolumn{8}{|c|}{ Base saturation (BS) [\%] } \\
\hline 0 & 71.59 & 75.88 & 71.40 & 72.79 & 66.39 & 83.88 & 73.66 \\
\hline 20 & 65.32 & 72.47 & 69.45 & 69.65 & 68.32 & 81.56 & 71.13 \\
\hline 40 & 63.30 & 68.14 & 66.77 & 73.95 & 67.33 & 86.05 & 70.92 \\
\hline 80 & 60.37 & 66.93 & 64.16 & 64.69 & 59.78 & 85.22 & 66.86 \\
\hline 160 & 58.22 & 61.17 & 59.91 & 61.43 & 60.16 & 80.85 & 63.62 \\
\hline 320 & 58.23 & 68.93 & 58.20 & 62.52 & 58.92 & 81.60 & 64.73 \\
\hline Average & 62.84 & 68.92 & 64.98 & 67.51 & 63.48 & 83.19 & 68.49 \\
\hline$r$ & $-0.759^{* *}$ & -0.450 & $-0.918^{* *}$ & $-0.773^{* *}$ & $-0.789^{* *}$ & -0.492 & $-0.814^{* *}$ \\
\hline LSD & \multicolumn{7}{|c|}{$a-0.70^{* *}, b-0.70^{* *}, a \cdot b-1.71^{* *}$} \\
\hline
\end{tabular}

LSD (least squares deviation) for: $\mathrm{a}$ - cobalt dose, $\mathrm{b}-$ kind of neutralizing substance, $\mathrm{a} \cdot \mathrm{b}-$ interaction; significant for: ${ }^{* *}-\mathrm{P}=0.01^{*}-\mathrm{P}=0.05 ; \mathrm{r}-$ correlation coefficient.

Table 3. Correlation coefficients (r) between $\mathrm{pH}$, hydrolitic acidity, total exchangeable bases, cation exchange capacity and base saturation in soil

\begin{tabular}{|c|c|c|c|c|}
\hline Factor & HAC & TEB & CEC & BS \\
\hline $\mathrm{pH}_{\mathrm{KCl}}$ & $-0.949^{* *}$ & $0.926^{* *}$ & $0.865^{* *}$ & $0.948^{* *}$ \\
\hline $\mathrm{HAC}$ & - & $-0.906^{* *}$ & $-0.817^{* *}$ & $-0.966^{* *}$ \\
\hline TEB & - & - & $0.984^{* *}$ & $0.971^{* *}$ \\
\hline CEC & - & - & - & $0.920^{* *}$ \\
\hline
\end{tabular}

Explanations: $\mathrm{pH}_{\mathrm{KCl}}-\mathrm{pH}$ in $1 \mathrm{M} \mathrm{KCL}, \mathrm{HAC}-$ hydrolitic acidity, TEB - total exchangeable bases, CEC - cation exchange capacity, BS - base saturation.

** significant for $\mathrm{p}=0,01$

\section{CONCLUSIONS}

1. In the series without neutralising substances added, soil contamination with the highest doses of cobalt resulted in a decrease in $\mathrm{pH}$, in the total exchangeable bases, in the cation exchange capacity, and in the base saturation, and in an increase in the soil hydrolytic acidity.

2. Of the applied neutralising substances, farmyard manure and particular calcium oxide had the greatest effect on the analysed soil properties. The application of the substances resulted in an increase in the soil $\mathrm{pH}$, in the base exchange capacity, in the cation exchange capa- city and in the base saturation and also in a decrease in the soil hydrolytic acidity.

3. The other substances had no or a small effect on the studied soil properties.

\section{REFERENCES}

1. Azeez J.O., Van-Averbeke W. 2012. Dynamics of soil $\mathrm{pH}$ and electrical conductivity with the application of three animal manures. Communications in Soil Science and Plant Analysis, 43(6), 865-874.

2. Bezerra J.D., Santos-Amaral R., Santos-Junior J. A., Genezini F.A., Cezar-Menezes R.S., Oliviera 
I.A. 2014. Characterization of Heavy Metals in a Uranium Ore Region of the State of Pernambuco, Brazil. Bulletin of Environmental Contamination and Toxicology, 92, 270-273.

3. Biswas S., Dey R., Mukherjee S., Banerjee P. C. 2013. Bioleaching of nickel and cobalt from lateritic chromite overburden using the culture filtrate of Aspergillus niger. Applied Biochemistry and Biotechnology, 170, 1547-1559.

4. Chatterjee J., Chatterjee C. 2002. Amelioration of phytotoxicity of cobalt by high phosphorus and its withdrawal in tomato. Journal of Plant Nutrition, 25 (12), 2731-2743.

5. Collins R.N., Kinsela A.S. 2011. Pedogenic factors and measurements of the plant uptake of cobalt. Plant and Soil 339, 499-512.

6. Devi G., Goplal-Bhattacharyya L.B.M., Devi A. 2014. Trace metal composition of PM2,5, soil and Machilus bombycina leaves and the effects on Antheraea assama silk worm rearing in the oil field area of Northeastern India. Water Air and Soil Pollution, 225, 1884-1897.

7. Edwards A.C., Cuull M., Sinclair A.H., Walker R.L., Watsun C.A. 2012. Elemental status (Cu, Mo, $\mathrm{Co}, \mathrm{B}, \mathrm{S}, \mathrm{Zn}$ ) of Scottish agricultural soils compared with a soil-based risk assessment. Soil Use and Management, 28, 167-176.

8. Filcheva E. G., Tsadilas C. D. 2002. Influence of clinoptilolite and compost on soil properties. Communications in Soil Science and Plant Analysis, 33 (3/4), 595-607.

9. Glisic I.P., Milosevic T.M., Glisic I.S., Milosevic N.T. 2009. The effect of natural zeolites and organic fertilisers on the characteristics of degraded soils and yield of crops grown in Western Serbia. Land Degradation and Development, 20, 33-40.

10. Karuppanapandian T., Kim W. 2013. Cobalt induced oxidative stress causes growth inhibition associated with enhanced lipid peroxidation and activates antioxidant responses in Indian mustard (Brassica juncea L.) leaves. Acta Physiologiae Plantarum, 35, 2429-2443.

11. Kierczak J., Neel C., Aleksander-Kwaterczak U., Helios-Rybicka E., Bril H., Puziewicz J. 2008. Solid speciation and mobility of potentially toxic elements from natural and contaminated soils: A combined approach, Chemosphere, 73(5), 776-784.

12. Kosiorek M., Wyszkowski M. 2016. Selected properties of cobalt-contaminated soil following the application of neutralising substances, Environmental Protection and Natural Resources, 27, 1(67), 22-25.

13. Kukier U., Peters C.A., Chaney R.L., Angle J.S., Roseberg R.J. 2004. The effect of $\mathrm{pH}$ on metal accumulation in two Alyssum species. Journal of Environmental Quality, 33(6), 2090-2102.

14. Lange B., Faucon M.P., Meerts P., Shutcha M., Mahy G., Pourret O. 2014. Prediction of the edaphic factors influence upon the copper and cobalt accumula- tion in two metallophytes using copper and cobalt speciation in soils. Plant and Soil, 379, 275-287.

15. Li Z., Feng X., Bi X., Li G., Lin Y., Sun G. 2014. Probing the distribution and contamination levels of 10 trace metal/metalloids in soil near a $\mathrm{Pb} / \mathrm{Zn}$ smelter in Middle China. Environmental Science and Pollution Research, 21, 4149-4162.

16. Luo D., Zheng H., Chen Y., Wang G., Fenghua D. 2010. Transfer characteristics of cobalt from soil to crops in the suburban areas of Fujian Province, southeast China. Journal of Environmental Management, 91, 2248-2253.

17. Micó C., Li H. F., Zhao F. J., Mcgrath S. P. 2008. Use of Co speciation and soil properties to explain variation in Co toxicity to root growth of barley (Hordeum vulgare L.) in different soils. Environmental Pollution, 156 (3), 883-890.

18. Ostrowska A., Gawliński S., Szczubałka Z. 1991. Methods for analysis and evaluation of soil and plant properties. IOŚ Warszawa.

19. Saaltink R., Griffioen J., Mol G., Birke M. 2014. Geogenic and agicultural controls on the geochemical composition of European agricultural soils. Journal of Soil and Sediments, 14, 121-137.

20. Singh B., Bochereau F. J. M., Alloway B. J. 2000. Cadmium sorption behavior of natural and synthetic zeolites. Communications in Soil Science and Plant Analysis, 31 (17/18), 2775-2786.

21. Wendling L.A., Kirbz J.K., Mclaughlin M.J. 2009. Aging effects on cobalt availability in soils. Environmental Toxicology and Chemistry, 28(8), 1609-1617.

22. Werkenthin M., Kluge B., Wessolek G. 2014. Metals in European roadside soils and soil solution - A review. Environmental Pollution, 189, 98-110.

23. Wyszkowski M., Modrzewska B. 2016. Acidity and sorption properties of zinc-contaminated soil following the application of neutralising substances. Journal of Ecological Engineering, 17(1), 63-68.

24. Wyszkowski M., Sivitskaya V. 2015. Effect of different substances on some properties of soil contaminated with heating oil. Journal of Ecological Engineering, 16(1), 62-66.

25. Wyszkowski M., Wyszkowska J. 2007. The content of macroelements in spring barley (Hordeum vulgare $L$.) and theirs relations with the enzymatic activity of cobalt contaminated soil. Proceeding of SECOTOX Conference and the International Conference on Environmental Management, Engineering, Planning and Economics, 1, 181-186.

26. Wyszkowski M., Wyszkowska J. 2009. The effect of contamination with cadmium on spring barley (Hordeum vulgare L.) and its relationship with the enzymatic activity of soil. Fresenius Environmental Bulletin, 18(7), 1046-1053.

27. Zupancic N., Skobe S. 2014. Antropogenic environment al impact in the Mediterranean coastal area of Koper/Capodistria, Slovenia. Journal of Soils and Sediments, 14, 67-77. 